\title{
GAMBARAN HISTOPATOLOGI PANKREAS, HATI ,GINJAL Rattus Norvegicus DENGAN PEMBERIAN EKSTRAK Lagerstroemia speciosa [L.]Pers
}

\author{
Adelgrit Trisia ${ }^{1}$, Indria Augustina ${ }^{2}$ \\ Program Studi Pendidikan Dokter, Fakultas Kedokteran, Universitas Palangka Raya \\ Palangka Raya, Kalimantan Tengah, Indonesia \\ E-mail: adelgrit_trisia@yahoo.com
}

\begin{abstract}
ABSTRAK
Latar Belakang: Diabetes Melitus (DM) merupakan penyakit metabolik dengan karakteristik hiperglikemia yang terjadi karena kelainan sekresi insulin, kerja insulin atau keduanya. Di Indonesia kejadian diabetes mencapai $2,1 \%$ berdasarkan diagnosis dokter, sedangkan angka kejadian diabetes melitus di Kalimantan Tengah tahun 2013 mencapai 1,6\%. Bungur (Lagerstroemia speciosa (L.) Pers) dipercaya masyarakat kalimantan Tengah mampu menyembuhkan berbagai penyakit, salah satunya diabetes melius. Tujuan: Penelitian dilakukan untuk mengetahui pengaruh pemberian ekstrak bungur (Lagerstroemia speciosa $(L$.) Pers) terhadap perubahan gambaran histopatologi pankreas, hati dan ginjal Tikus (Rattus norvegicus) Model diabetes melitus yang diinduksi Streptozotosin. Metode: Subjek penelitian menggunakan pankreas, hati dan ginjal tikus putih jantan galur wistar, batang bungur (Lagerstroemia speciosa [L.] Pers.). Penelitian ini menggunakan 3 kelompok kontrol dan 3 kelompok perlakuan, yaitu kontrol normal, kontrol negatif, Glibenklamid sebagai kontrol positif, dan ekstrak batang bungur (Lagerstroemia speciosa[L.]Pers) dengan dosis 250 $\mathrm{mg} / \mathrm{KgBB}, 500 \mathrm{mg} / \mathrm{KgBB}$, dan $1000 \mathrm{mg} / \mathrm{KgBB}$. Tikus diberi perlakuan dan hari ke 28 dilakukan pengambilan sampel organ. Hasil: Histopatologi pankreas, hepar dan ginjal menunjukan perbaikan setelah pemberian ekstrak batang bungur, dimana pada dosis $500 \mathrm{mg} / \mathrm{kgBB}$ memberikan gambaran perbaikan sel terbaik mendekati kontrol normal Kesimpulan: Ekstrak bungur (Lagerstroemia speciosa (L.) Pers) berpengaruh terhadap perbaikan sel.
\end{abstract}

Kata Kunci: Bungur (Lagerstroemia speciosa (L.) Pers), Histopatologi, Pankreas, Hati, Ginjal, Tikus (Rattus Norvegicus), Diabetes Melitus, Streptozotocin (Stz)

\begin{abstract}
Background: Diabetes mellitus is a metabolic disease with the characteristics of hyperglycemia that occurs due to abnormal insulin secretion, insulin action or both. In Indonesia the incidence of diabetes reaches $2.1 \%$ based on a doctor's diagnosis, while the incidence of diabetes mellitus in Central Kalimantan in 2013 reached 1.6\%. Bungur (Lagerstroemia speciosa (L.) Pers) is believed by the people of Central Kalimantan to be able to cure various diseases, one of them is diabetes mellitus. Objective: The study was conducted to determine the effect of bungur extract (Lagerstroemia speciosa (L.) Pers) on changes in histopathological features of the pancreas, liver and kidney of the Rat (Rattus norvegicus) model of diabetes mellitus induced by Streptozotosin. Method: Subjects used were pancreas, liver and kidney of male white rat wistar strain, Bungur stem (Lagerstroemia speciosa [L.] Pers.). This study used 3 control groups and 3 treatment groups, namely normal control, negative control, Glibenclamide as positive control, and Bungur stem extract (Lagerstroemia speciosa [L.] Pers) with a dose of $250 \mathrm{mg} / \mathrm{KgBB}, 500 \mathrm{mg} / \mathrm{KgBB}$, and $1000 \mathrm{mg} / \mathrm{KgBB}$. Rat (Rattus norvegicus) were treated and the 28th day was taken organ sampling. Results: Pancreatic histopathology showed improvement after administration of bungur stem extract, which at a dose of $500 \mathrm{mg} / \mathrm{kgBB}$ gave the best cell repair. Conclusion: Bungur extract (Lagerstroemia speciosa (L.) Pers) affected the repair of cells..
\end{abstract}


Keywords: Bungur (Lagerstroemia speciosa (L.) Pers), Histopathology, Pancreas, Liver, Kidney, Rat (Rattus Norvegicus), Diabetes Melitus, Streptozotocin (STZ) 


\section{PENDAHULUAN}

Secara global sekitar 422 juta orang dewasa mengalami diabetes melitus pada tahun 2014, dibandingkan pada tahun 1980 sekitar 108 juta orang. Prevalensi secara global meningkat dua kali lipat sejak tahun 1980 yaitu dari 4,7 \%-8,5 \% pada populasi orang dewasa. Peningkatan diabetes ini juga bersamaan juga dengan faktor risiko berupa kelebihan berat badan atau obesitas (WHO tahun 2014). ${ }^{1}$ Di Indonesia kejadian diabetes mencapai 2,1\% berdasarkan diagnosis dokter, sedangkan angka kejadian diabetes melitus di Kalimantan Tengah tahun 2013 berdasarkan Riset Kesehatan Dasar mencapai 1,6\%. Hal ini cukup mengkhawatirkan karena kejadian meningkat seiring bertambahnya usia, namun mulai menurun menginjak usia $\geq 65$ tahun. $^{2}$

Imunologi adalah cabang ilmu biomedis yang berkaitan dengan respons organisme terhadap penolakan antigenik, pengenalan diri sendiri dan bukan dirinya, serta semua efek biologis, serologis dan kimia fisika fenomena imun. Diabetes melitus (DM) tipe 1 adalah penyakit autoimun kronis yang berhubungan dengan kehancuran selektif sel beta pankreas yang memproduksi insulin. Timbulnya penyakit klinis merupakan tahap akhir dari kerusakan sel beta yang mengarah ke tipe 1 DM. Berbagai lokus gen telah dipelajari untuk menentukan hubungan dengan DM tipe 1, lokus HLA-DR kelas II dan ditemukan bahwa DR3 dan DR4 lebih menonjol daripada HLA-B pada DM tipe 1. Sel Islet tertentu pada baris sel beta memproduksi antibodi IgG yang terikat ke antigen sitoplasma sel islet yang ditemukan. Diabetes Melitus (DM) merupakan suatu kelompok penyakit metabolik dengan karakteristik hiperglikemia yang terjadi karena kelainan sekresi insulin, kerja insulin atau kedua-duanya. Terdapat 2 tipe diabetes, yaitu diabetes melitus tipe I atau IDDM (Insulin Dependent Diabetes Mellitus) terjadi karena rusaknya sel $\beta$ pankreas yang mengakibatkan jumlah sekresi hormon insulin berkurang, sehingga tidak mampu mengambil glukosa dari sirkulasi darah dan tidak mampu mengontrol kadar glukosa dalam darah. Diabetes melitus tipe II atau NIDDM (Non Insulin Dependent Diabetes Mellitus) terjadi karena resistensi insulin, jumlah insulin cukup tetapi insulin tersebut tidak sensitif lagi sehingga tidak mampu bekerja secara optimal dan glukosa tidak dapat masuk ke dalam sel yang mengakibatkan penggunaan glukosa sebagai energi menjadi terhambat sehingga menyebabkan hiperglikemia. ${ }^{3}$ Hiperglikemia adalah suatu kondisi medik berupa peningkatan kadar glukosa dalam darah melebihi batas normal. Hiperglikemia merupakan salah satu tanda khas penyakit Diabetes Melitus (DM). ${ }^{4}$ Peningkatan glukosa menghasilkan akumulasi Reactive Oxygen Species (ROS) pada sel $\beta$ pankreas. Akumulasi ROS ini akan merusak sel tempatnya berada. Pada diabetes tipe 2 , ROS menurunkan sintesis insulin dan mengaktifkan jaras apoptosis sel $\beta .^{5}$

Pengembangan berbagai jenis obat semakin banyak dilakukan seiring dengan bertambahnya penyakit-penyakit jenis baru, atau akibat resistensi dan efek samping dari obat tersebut. Salah satu pengobatan yang banyak dikembangkan adalah pengobatan tradisional. Masyarakat di negara berkembang umumnya masih menggunakan pengobatan tradisional. Pengembangan tanaman obat telah banyak dilakukan untuk menemukan obatobat baru yang berguna untuk mengobati berbagai macam penyakit yang sekarang sulit diobati. Indonesia memiliki banyak sekali tanaman yang dikenal berkhasiat obat. ${ }^{6} \mathrm{Di}$ Kalimantan Tengah, salah satu tanaman yang sering dimanfaatkan sebagai obat tradisional adalah Bungur. Tanaman ini juga terdapat di Filipina dan Malaysia. ${ }^{7}$

Bungur (Lagerstroemia speciosa (L.) Pers) dipercaya masyarakat mampu menyembuhkan berbagai penyakit, seperti tekanan darah tinggi, diabetes, kencing batu, kencing darah, diare, dan disentri. Bagian yang sering dikonsumsi oleh masyarakat adalah biji, daun dan kulit kayu. ${ }^{8}$ Menurut penelitian Astiti Asih, terdapat kandungan flavonoid pada batang bungur, flavonoid sendiri memiliki aktivitas hipoglikemik dengan menghambat enzim pemecah karbohidrat pada saluran pencernaan. ${ }^{9}$ Selain itu, flavonoid juga berperan sebagai antioksidan. Aktivitas sebagai antioksidan dimiliki oleh flavonoid disebabkan adanya gugus hidroksi fenolik dalam stuktur molekulnya. Ketika senyawa-senyawa ini 
bereaksi dengan radikal bebas, mereka membentuk radikal baru yang stabil. ${ }^{10}$

$$
\text { Penelitian ini menggunakan }
$$

streptozotosin untuk menginduksi kondisi diabetes melitus pada hewan coba. Berdasarkan penelitian yang dilakukan oleh Fiizhda Baqarizky tahun 2015 dilaporkan bahwa pankreas tikus yang diinduksi streptozotosin mengalami proses nekrosis, kemungkinan hal ini terjadi akibat efek streptozotosin yang dapat mendestruksi sel $\beta$ pankreas. ${ }^{11}$ Streptozotosin dapat masuk ke dalam sel $\beta$ pankreas dengan bantuan Glucose Transporter-2 (GLUT-2) sehingga bersifat selektif toksik terhadap sel-sel tersebut. Ketika Deoxyribose-Nucleic Acid (DNA) sel tersebut sudah rusak maka akan mengaktivasi poli ADP-ribosilase dan pada akhirnya akan terbentuk radikal bebas yang dapat merusak sel $\beta$ pankreas. ${ }^{12}$ Oleh karena itu, penelitian ini bertujuan untuk Membuktikan pengaruh pemberian ekstrak bungur (Lagerstroemia speciosa (L.) Pers) terhadap perubahan gambaran histopatologi pancreas, hati dan ginjal Tikus (Rattus norvegicus) Model diabetes melitus yang diinduksi Streptozotosin.

\section{METODE PENELITIAN}

Penelitian ini merupakan True Experimental Design yang menggunakan Posttest Control Group Design dengan 6 variabel perlakuan. Dimana metode ini peneliti melihat gambaran histopatologi pankreas pada diabetes melitus yang diberi terapi Ekstrak Batang Bungur (Lagerstroemia speciosa [L.] Pers) pada tikus putih jantan (Rattus norvegicus)

Sampel yang diteliti adalah Tikus Jantan (Rattus norvegicus)yang nanti akan dibagi menjadi 6 kelompok perlakuan, tiap kelompok terdapat 5 subjek penelitian. 6 kelompok tersebut terbagi menjadi: Kontrol Positif, Kontrol Negatif dan sisanya menjadi kontrol perlakuan. Kelompok perlakuan dibagi menjadi 5 kelompok yaitu:
1. Kelompok Kn : Kelompok Tikus Yang Tidak diinduksi Streptozotocin (Na- CMC 1\%) (Kontrol Normal)
2. Kelompok K(-) : Kelompok Tikus Yang diinduksi Streptozotocin + Na- CMC $1 \%$ (Kontrol Negatif)

3. Kelompok $\mathrm{K}(+)$ : Kelompok Tikus Yang diinduksi Streptozotocin + Obat Glibenklamid (Kontrol Positif).

$\begin{array}{ll}\text { 4. Kelompok P4 : } & \text { Kelompok Tikus } \\ & \text { Yang diinduksi } \\ & \text { Streptozotocin + } \\ & \text { Ekstrak Batang } \\ & \text { Bungur dengan dosis } \\ & 250 \mathrm{mg} / \mathrm{kgBB} .\end{array}$

5. Kelompok P5 : Kelompok Tikus Yang diinduksi Streptozotocin + Ekstrak Batang Bungur dengan dosis $500 \mathrm{mg} / \mathrm{kgBB}$.

$\begin{array}{ll}\text { 6. Kelompok P6 : } & \text { Kelompok Tikus Yang } \\ & \text { diinduksi } \\ & \text { Streptozotocin + } \\ & \text { Ekstrak Batang } \\ & \text { Bungur dengan dosis } \\ & 1000 \mathrm{mg} / \mathrm{kgB} .\end{array}$

Sampel yang diteliti adalah Tikus Jantan (Rattus norvegicus) yang sesuai dengan kriteria inklusi. Teknik pengambilan sampel ini dilakukan secara simple random sampling. Simple random sampling merupakan pengambilan anggota sampel dari populasi dilakukan secara acak tanpa memperhatikan strata yang ada dalam populasi itu.

Penelitian ini menggunakan 6 kelompok dengan masing-masing kelompok terdapat 5 ekor Tikus putih jantan galur wistar. Sehingga jumlah Tikus putih jantan galur wistar yang dijadikan sampel adalah sebanyak 30 ekor. Dari masing - masing hewan coba di lakukan pembuatan preparat histopatologi Pankreas, hati dan ginjal.

Penelitian ini menggunakan 6 kelompok dengan masing-masing kelompok terdapat 5 ekor Tikus putih jantan galur wistar. Sehingga jumlah Tikus putih jantan galur wistar yang dijadikan sampel adalah sebanyak 30 ekor. Dari masing - masing hewan coba di lakukan 
pembuatan preparat histopatologi Pankreas, hati dan ginjal.

Variabel dependen yaitu Sajian histologi berupa organ pankreas, hati dan ginjal tikus yang di potong dengan mikrotom, sedangkan kriteria dependen adalah Ekstrak batang bungur adalah sediaan yang diperoleh dengan mengekstrasi zat aktif tumbuhan dengan etanol melalui proses maserasi. Kemudian dibuat larutan dengan berbagai dosis menggunakan karboksi metil selulosa. Dosis yang digunakan adalah $250 \mathrm{~g} / \mathrm{KgBB}, \quad 500 \mathrm{~g} / \mathrm{KgBB}, \quad 1000$ $\mathrm{g} / \mathrm{KgBB}$

Alat-alat yang akan digunakan dalam penelitian ini yaitu: Kandang hewan, tempat pakan hewan ternak, sonde, sarung tangan, alatalat gelas (Pyrex), rotaryevaporator, blender, jarum suntik, disposable syringe $1 \mathrm{ml}$, gunting, alat ukur glukosa darah, timbangan, masker, Minor set surgeon, cetakan blocking dan spritus, mikrotom, object glass, cover glass, mikroskop.

Bahan yang digunakan dalam penelitian ini yaitu : pankreas, hati dan ginjal tikus putih jantan galur wistar, batang bungur (Lagerstroemia speciosa [L.] Pers.), etanol 96\%, aquades, PBS (phosphate buffer saline), formalin, xylol, hematoksilin, eosin, sreptozotocin dan glibenklamid.

Semua tikus putih dimasukkan ke dalam kandang terpisah untuk adaptasi selama satu minggu. Selama masa adaptasi semua tikus putih diberi makan dan air minum yang sama yaitu BR2 dan aquades.

Penentuan dosis EEBB yaitu250 $\mathrm{mg} / \mathrm{kgBB}, 500 \mathrm{mg} / \mathrm{kgBB}, 1000 \mathrm{mg} / \mathrm{kgBB} .^{33,34}$

Dosis Glibenklamid pada manusia dewasa adalah $5 \mathrm{mg}$, dengan dosis konversi dari manusia ke tikus adalah 0,018. Maka dosis Glibenklamid untuk tikus adalah $5 \mathrm{mg}$ x 0,018 $=0,09 \mathrm{mg} /$ tikus $200 \mathrm{~g}$. $0,09 \times 5$ ekor x 14 hari $=31, \mathrm{mg}$. Sehingga tablet Glibenklamid digerus dan diambil sebanyak $31,5 \mathrm{mg}$, ditambahkan suspensi CMC 1,0\% sedikit demi sedikit sambil digerus sampai homogen, volume dicukupkan hingga $70 \mathrm{ml}$.

\section{Pembuatan Larutan Ekstrak Etanol Batang Bungur}

a. Batang Bungur sebanyak $10 \mathrm{~kg}$ terlebih dahulu dibersihkan dibawah air mengalir, untuk membersihkan dari kotoran.

b. Batang dijemur dibawah sinar matahari selama 4 hari hingga kadar air berkurang hingga tersisa $10 \%$, dalam hal ini dapat menggunakan oven sebagai alat bantu, dengan $100^{\circ} \mathrm{c}$ selama 15 menit.

c. Setelah batang bungur kering, dilakukan pengecilan ukuran batang bungur dengan menggunakan pisau.

d. Sebelum dilakukan ekstraksi secara maserasi, simplisia batang bungur sebanyak 1,2 $\mathrm{kg}$ di blender dengan tujuan memperkecil ukuran batang bungur sehingga memperluas permukaan yang akan bersentuhan dengan pelarut.

e. Pelarut yang digunakan adalah etanol $96 \%$ karena merupakan larutan universal yang dapat melarutkan senyawa bersifat polar, semipolar, dan non polar.

f. Seluruh batang bungur yang telah diblender kemudian di maserasi dengan etanol $96 \%$.

g. Maserasi dilakukan selama 3x24 jam pada hari berikutnya pelarut diganti sambil sesekali dilakukan pengadukan, untuk mencegah terjadinya kejenuhan dan pada hari berikutnya pelarut diganti setiap hari.

h. Maserator ditutup, dibiarkan di tempat sejuk, terlindung dari cahaya.

i. Setelah 4 hari maserat disaring sehingga memperoleh ampas dan filtrate (ekstrak cair).

j. Dilakukan pemekatan menggunakan rotary cavuum evaporator pada suhu $40-50^{\circ} \mathrm{C}$.

k. Proses evaporasi dilakukan selama 4 hari hingga ekstrak agar pekat.

1. Larutan ekstrak dibuat larutan dengan 3 variasi dosis $250 \mathrm{mg} / \mathrm{kgBB}, 500$ $\mathrm{mg} / \mathrm{kgBB}, 1000 \mathrm{mg} / \mathrm{kgBB}$. Larutan perlakuan dibuat dengan menggunakan larutan $\mathrm{CMC} 1 \%$ dibuat dengan melarutkan CMC 1gram dalam 
akuades hingga mengembang sampai larutan dihaluskan.

\section{Perlakuan Hewan Coba}

Prosedur Perlakuan Hewan Coba Sebagai Berikut:

a. Tikus putih ditimbang berat badannya dan kemudian dikelompokkan menjadi 6 kelompok dan ditempatkan secara terpisah.

b. Hewan uji akan diadaptasi/ aklimatisasi selama 7 hari

c. Hari ke 8 mengambil sampel darah hewan pada menit ke 0 untuk menentukan kadar trigliserida awal.

d. Selanjutnya sampel tikus putih $\mathrm{K}(+)$, $\mathrm{K}(-), \quad \mathrm{K} 1, \quad \mathrm{~K} 2, \quad \mathrm{~K} 3$ diinduksi streptozotocin dengan dosis $60 \mathrm{mg} / \mathrm{kg}$ BB tikus uji secara intra-peritoneal. Setelah diinduksi tikus tetap diberikan makanan dan minuman ad libitum, tunggu dalam 7 hari, lalu ukur kadar glukosa darahnya. Tikus dianggap diabetes apabila kadar glukosa darah $180-500 \mathrm{mg} / \mathrm{dl}$. Selanjutnya disebut sebagai tikus diabetes.

e. Hari ke 14 sampai hari ke 28 atau selama 14 hari dilakukan perlakuan terhadap hewan coba dan hari ke 28 dilakukan pengambilan sampel organ unutk pemeriksaan histopatologi pankreas, hati dan ginjal.

f. Memberikan sediaan Glibenklamid oral satu kali pagi hari setiap hari selama 14 hari waktu makan, ke hewan uji dengan menggunakan sonde lambung yang akan menjadi kontrol positifnya.

g. Memberikan sediaan larutan uji ekstrak batang bungur dengan dosis $250 \mathrm{mg} / \mathrm{kgBB}, 500 \mathrm{mg} / \mathrm{kgBB}, 1000$ $\mathrm{mg} / \mathrm{kgBB}$ Selama 14 hari. Pemberian menggunakan sonde lambung. Tikus tetap diberikan makan dan minum ad libitum.

h. Menganalisis hasil dari histopatologi tikus putih galur wistar, yaitu :

1) Pembuatan Preparat Histopatologi

2) Pewarnaan Hematoksilin Eosin

3) Pemeriksaan Preparat Histopatologi

\section{HASIL PENELITIAN}

Dari hasil penapisan fitokimia, terlihat bahwa simplisia dan ekstrak etanol batang Bungur (Lagerstroemia speciosa [L.] Pers) mengandung berbagai senyawa kimia, seperti terlihat pada Tabel 1.

Tabel 1. Hasil penapisan fitokimia simplisia dan ekstrak etanol batang Bungur (Lagerstroemia speciosa [L.] Pers)

\begin{tabular}{llcc}
\hline \hline Senyawa Fitokimia & Metode & Kadar & Keterangan \\
\hline Saponin (\%) & Gravimetri & $17.632 \pm 0.520$ & Duplo \\
\hline Alkaloid (\%) & Gravimetri & $15.368 \pm 0.464$ & Duplo \\
\hline Flavonoid $(\mathrm{mg} \mathrm{EQ} / \mathrm{gram})$ & Kolorimetri & $49.102 \pm 0.166$ & Duplo \\
\hline Steroid $(\mathrm{mg} / \mathrm{mL})$ & Kolorimetri & $31.602 \pm 1.050$ & Duplo \\
\hline Tannin $(\mu \mathrm{M})$ & Kolorimetri & $34,006 \pm 0,326$ & Duplo \\
\hline
\end{tabular}

Berdasarkan tabel 1 di atas diketahui bahwa simplisia dan ekstrak etanol batang Bungur (Lagerstroemia speciosa [L.] Pers) memiliki kandungan saponin, alkaloid, flavonoid, steroid dan tanin. Batang Bungur memiliki kadar flavonoid dan tannin yang tinggi.

Penelitian ini merupakan True Experimental Design yang menggunakan Posttest Control Group Design dengan 6 variabel perlakuan. Dimana metode ini peneliti melihat gambaran histopatologi pancreas, hati, dan ginjal pada diabetes melitus yang diberi terapi Ekstrak Batang Bungur (Lagerstroemia speciosa [L.] Pers) pada tikus putih jantan (Rattus norvegicus)

Penelitian ini menggunakan 6 kelompok dengan masing-masing kelompok terdapat 5 ekor Tikus putih jantan galur wistar Kelompok perlakuan tersebut antara lain Kelompok 1 adalah kelompok tikus yang tidak diinduksi Streptozotocin dan disebut kontrol normal, kelompok 2 adalah kelompok tikus yang diinduksi Streptozotocin dan disebut kontrol negatif, kelompok 3 adalah kelompok tikus yang diinduksi Streptozotocin kemudian diberikan obat glibenklamid dan disebut kontrol positif, kelompok 4, 5 dan 6 adalah kelompok tikus yang diinduksi Streptozotocin kemudian kita berikan ekstrak batang bungur dengan dosis $250 \mathrm{gr} / \mathrm{kgBB}$, dosis $500 \mathrm{gr} / \mathrm{kgBB}$, 
dosis 1000 gr/kgBB. Dari masing - masing hewan coba di lakukan pembuatan preparat histopatologi pankreas, hati dan ginjal dengan pewarnaan hematoksilin eosin. seperti terlihat pada gambar 1 sampai gambar 18.

\section{Gambaran Histopatologi}

\section{Histopatologi Anatomi Pankreas}

\section{Kontrol (1)}
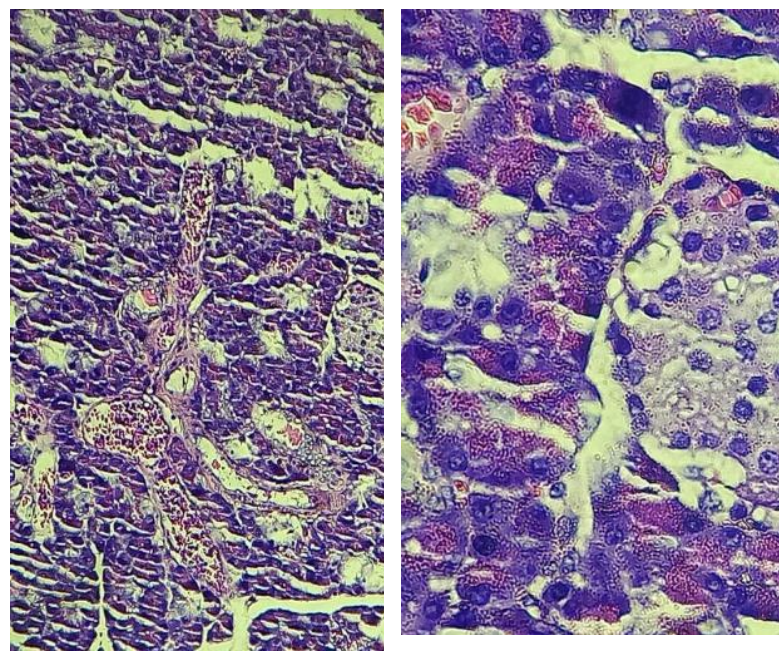

\section{Pankreas 1, 100x : $\quad$ Pankreas 1, 400x : Normal Normal}

Gambar 1. Jaringan pankreas terdiri dari kelenjar kecil-kecil dilapisi epitel kuboid selapis dengan inti bulat, relatif uniform, tersusun mikrofolikuler. Diantaranya tampak pulau-pulau langerhans yg lebih pucat, dengan inti bulat relatif uniform (Pembesaran 100x \& 400x)

\section{Kelompok (2)}

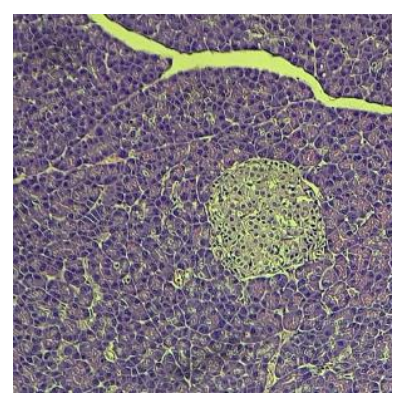

Perbesaran 100x

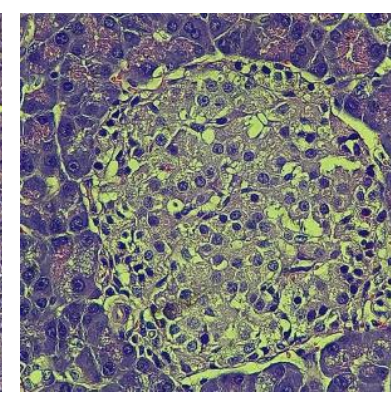

Perbesaran 400x
Gambar 2. Jaringan pankreas terdiri dari kelenjar kecil-kecil dilapisi epitel kuboid selapis dengan inti bulat, relatif uniform, tersusun mikrofolikuler. Diantaranya tampak pulau-pulau langerhans dgn sel lebih pucat, inti bulat, relatif uniform, sebagian sel tampak nekrosis, disertai sebukan sel radang kronik limfosit (Pembesaran $100 x \& 400 x)$

\section{Kelompok (3)}
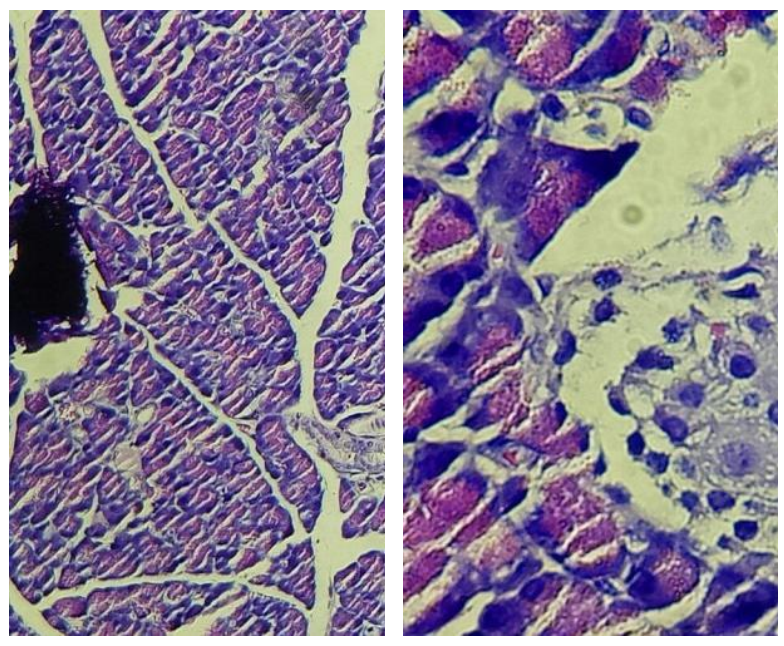

\section{Perbesaran 100x Perbesaran 400x}

Gambar 3. Jaringan pankreas terdiri dari kelenjar kecil-kecil dilapisi epitel kuboid selapis dengan inti bulat, relatif uniform, tersusun mikrofolikuler. Diantaranya tampak pulau-pulau langerhans dgn sel lebih pucat, dengan inti bulat relatif uniform. Tidak didapatkan nekrosis dan sel radang minimal. (Pembesaran 100x \& 400x)

\section{Kelompok (4)}
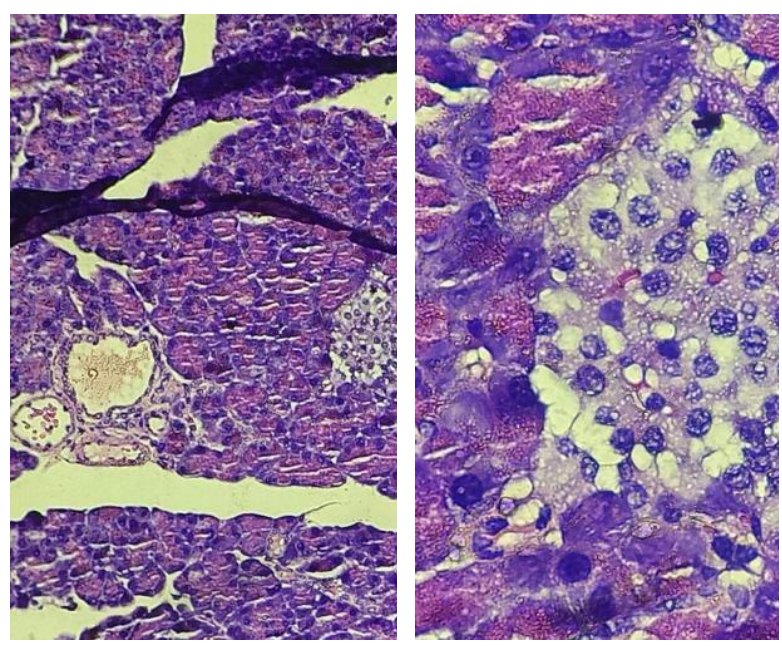

Perbesaran 100x 
Gambar 4. Jaringan pankreas terdiri dari kelenjar kecil-kecil dilapisi epitel kuboid selapis dengan inti bulat, relatif uniform, tersusun mikrofolikuler. Diantaranya tampak pulau-pulau

langerhans dgn sel lebih pucat, inti bulat, relatif uniform, tidak didapatkan sel nekrosis dan tampak sel radang minimal (Pembesaran 100x \& 400x)

\section{Kelompok (5)}

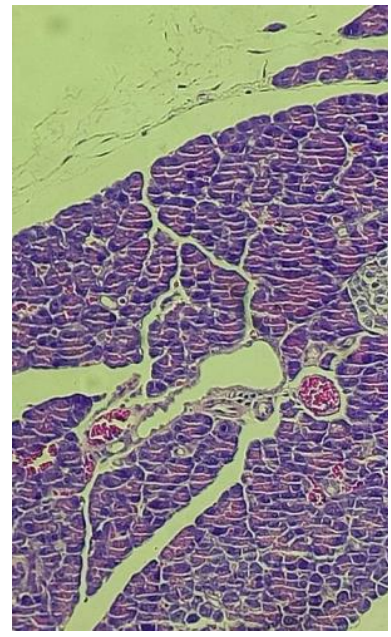

\section{Perbesaran 100x}

Gambar 5. Jaringan pankreas terdiri dari kelenjar kecil-kecil dilapisi epitel kuboid selapis dengan inti bulat, relatif uniform, tersusun mikrofolikuler. Diantaranya tampak pulau-pulau langerhans dgn sel lebih pucat, inti bulat, relatif uniform, tidak didapatkan sel nekrosis dan sel radang (Pembesaran 100x \& 400x)

\section{Kelompok (6)}

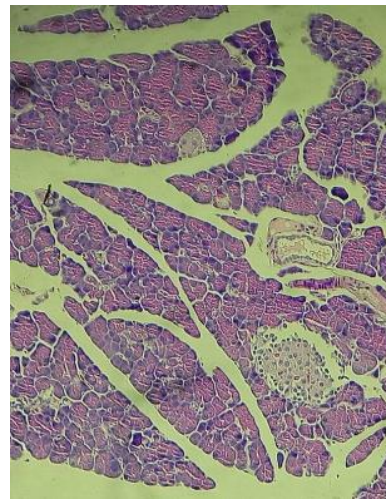

Perbesaran 100x

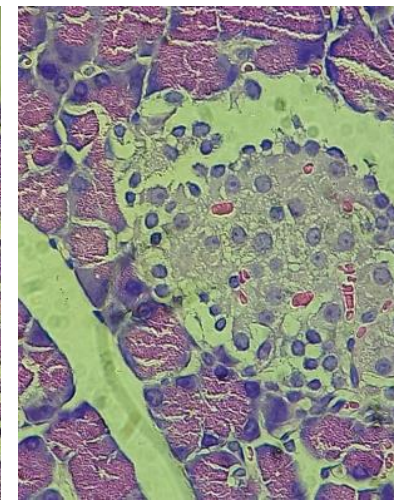

Perbesaran 400x
Gambar 6. Jaringan pankreas terdiri dari kelenjar kecil-kecil dilapisi epitel kuboid selapis dengan inti bulat, relatif uniform, tersusun mikrofolikuler. Diantaranya tampak pulau-pulau langerhans dgn sel lebih pucat, inti bulat, relatif uniform, tidak didapatkan sel nekrosis dan sel radang (Pembesaran 100x \& 400x)

\section{Histopatologi Anatomi Hati}

\section{Kelompok (1)}

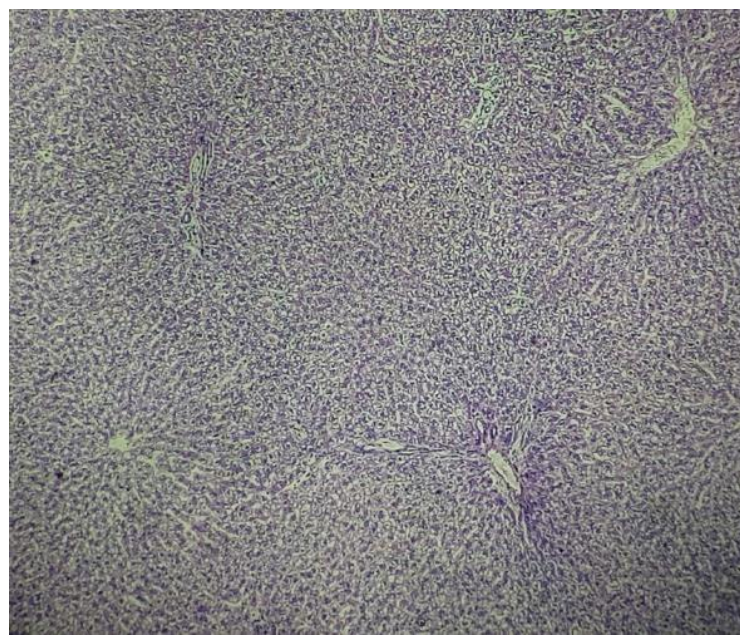

\section{Perbesaran 40x}

Gambar 7. Jaringan hati terdiri dari sel-sel hepatosit poligonal dgn inti bulat, kromatin halus, relatif uniform, tersusun regular diantara area porta. Tak didapatkan nekrosis maupun sebukan sel radang pada sediaan ini. (Pembesaran 40x \& 100x)

\section{Kelompok (2)}

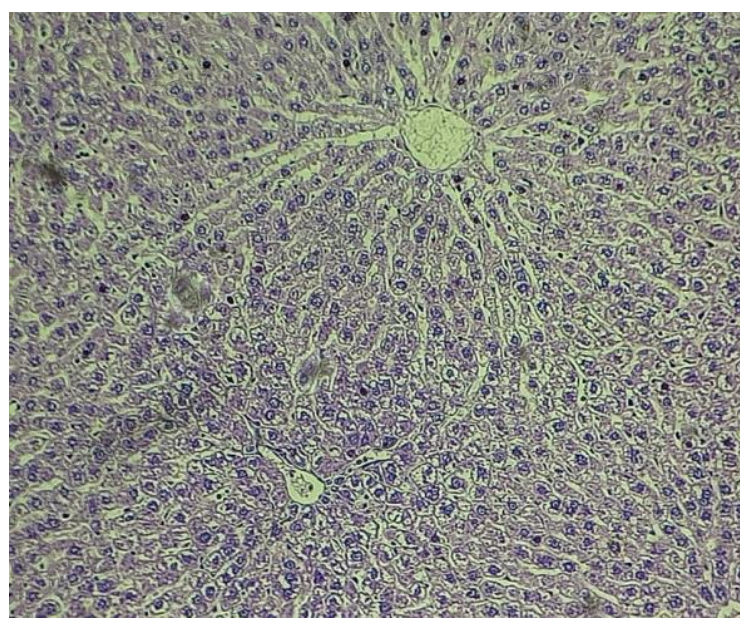

Perbesaran 100x 
Gambar 8. Jaringan hati terdiri dari sel-sel hepatosit poligonal dgn inti bulat, kromatin halus, relatif uniform, tersusun regular diantara area porta. Tak didapatkan nekrosis maupun sebukan sel radang pada sediaan ini.

\section{Kelompok (3)}

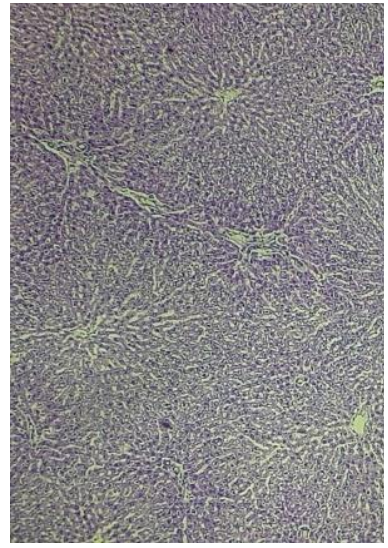

\section{Perbesaran 40x}

Gambar 9. Jaringan hati terdiri dari sel-sel hepatosit poligonal dgn inti bulat, kromatin halus, relatif uniform, tersusun regular diantara area porta. Tak didapatkan nekrosis maupun sebukan sel radang pada sediaan ini.

\section{Kelompok (4)}
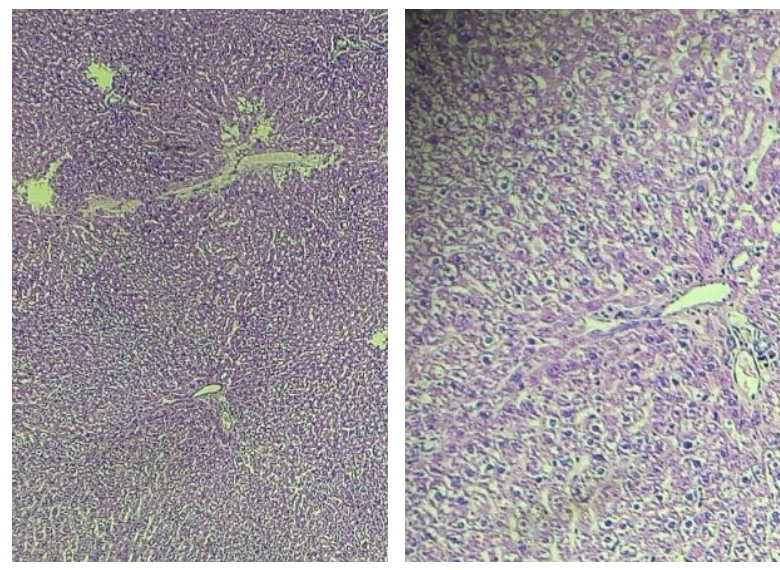

\section{Perbesaran 40x}

\section{Perbesaran 100x}

Gambar 10. Jaringan hati terdiri dari sel-sel hepatosit poligonal dgn inti bulat, kromatin halus, relatif uniform, tersusun regular diantara area porta. Tak didapatkan nekrosis maupun sebukan sel adang pada sediaan ini.

\section{Kelompok (5)}
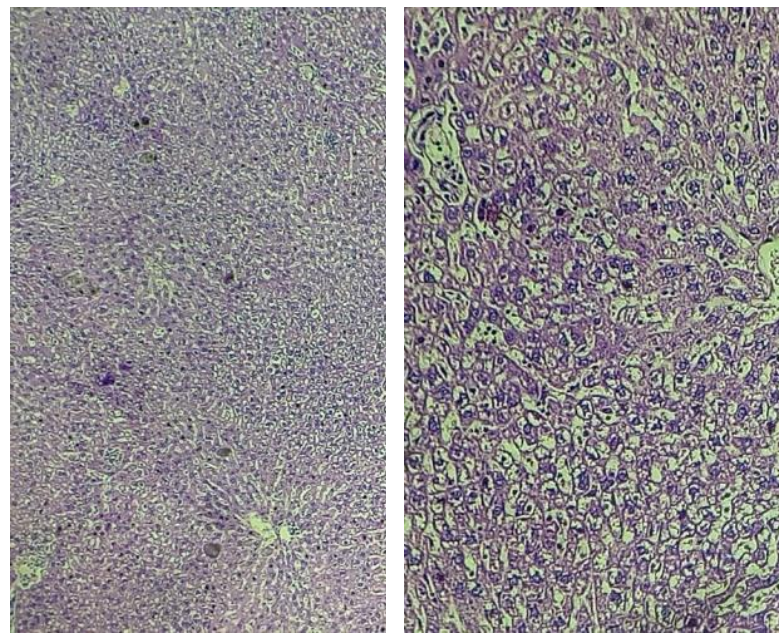

\section{Perbesaran 40x}

\section{Perbesaran 100x}

Gambar 11. Jaringan hati terdiri dari sel-sel hepatosit poligonal dgn inti bulat, kromatin halus, relatif uniform, tersusun regular diantara area porta. Tak didapatkan nekrosis maupun sebukan sel radang pada sediaan ini.

\section{Kelompok (6)}
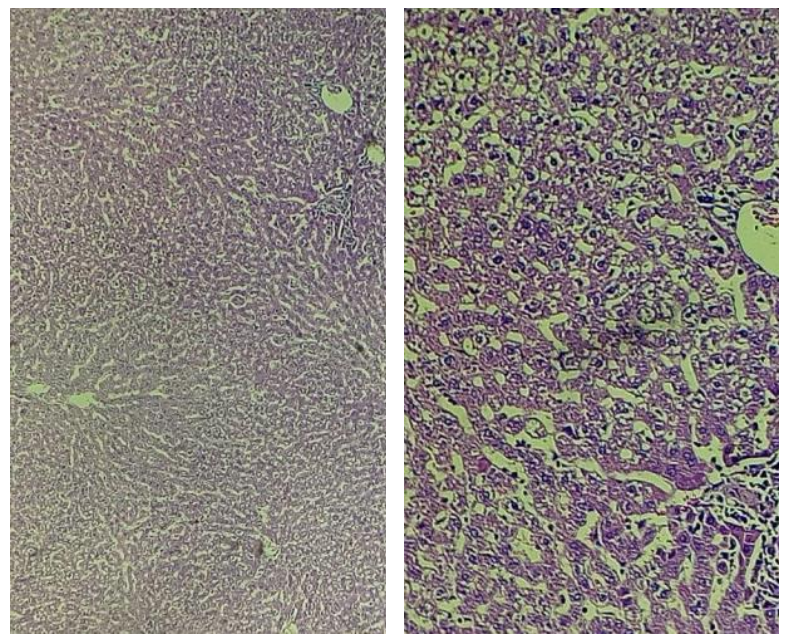

\section{Perbesaran 40x Perbesaran 100x}

Gambar 12. Jaringan hati terdiri dari sel-sel hepatosit berbentuk poligonal dgn inti bulat, relatif uniform, tersusun regular, terpisah dalam lobus-lobus. Tampak diantaranya area porta. Tampak pula sebukan moderat sel radang kronik limfosit setempat-setempat. 


\section{Histopatologi Anatomi Ginjal}

\section{Kelompok (1)}

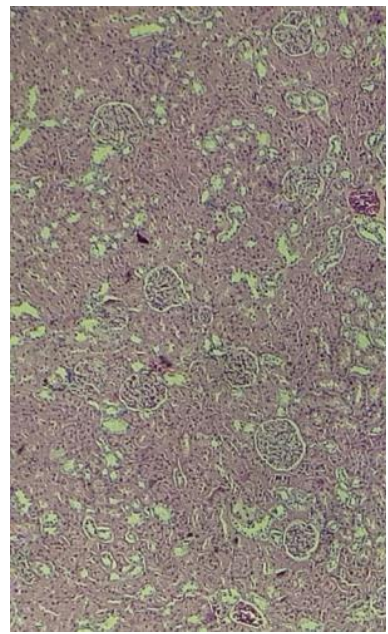

\section{Perbesaran 40x}

\section{Perbesaran 100x}

Gambar 13. Jaringan ginjal terdiri dari glumerulus dengan kapsula bowman terdiri dari sel dgn inti bulat, relatif uniform. Tampak tubulus tersusun rapat berstruktur tubulus dilapisi epitel kuboid selapis. Tak didapatkan nekrosis, tanda radang maupun keganasan. (Pembesaran 40x \& 100x)

\section{Kelompok (2)}

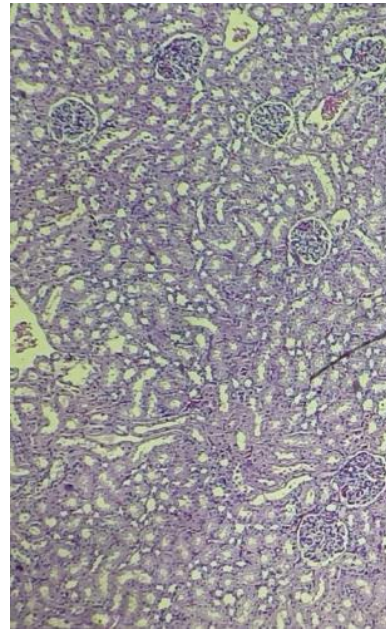

\section{Perbesaran 40x}

\section{Perbesaran 100x}

Gambar 14. Jaringan ginjal terdiri dari glumerulus dengan kapsula bowman terdiri dari sel dgn inti bulat, relatif uniform. Tampak tubulus tersusun rapat berstruktur tubulus dilapisi epitel kuboid selapis. Tak didapatkan nekrosis, tanda radang maupun keganasan.

\section{Kelompok (3)}
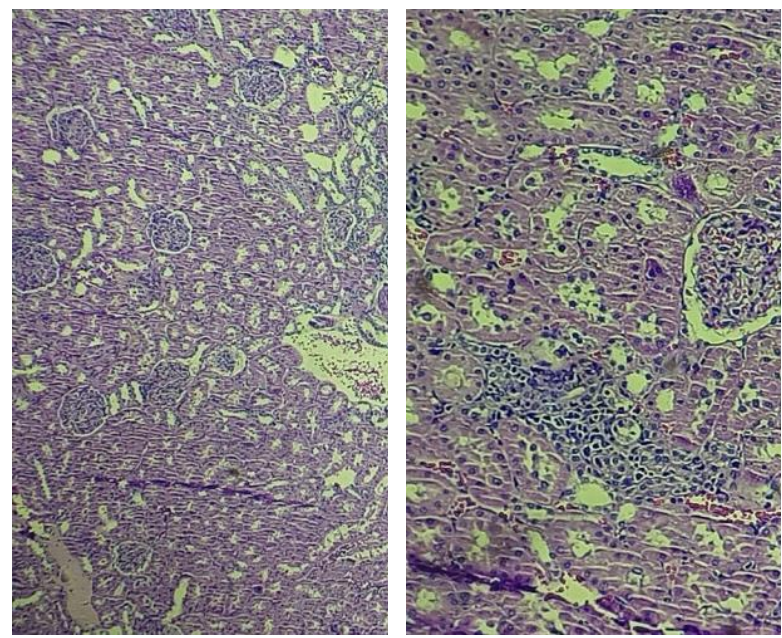

\section{Perbesaran 40x Perbesaran 100x}

Gambar 15. Jaringan ginjal terdiri dari glumerulus dengan kapsula bowman terdiri dari sel dgn inti bulat, relatif uniform. Tampak pula tubulus yg tersusun rapat, berstruktur tubulus, dilapisi epitel kuboid selapis. Diantaranya tampak sebukan moderat sel radang kronik limfosit setempat-setempat disertai bagian perdarahan. Tak didapatkan nekrosis maupun degenerasi pada sediaan ini.

\section{Kelompok (4)}

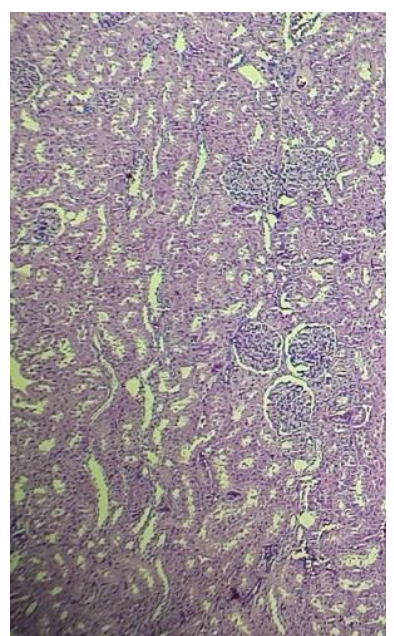

Perbesaran 40x

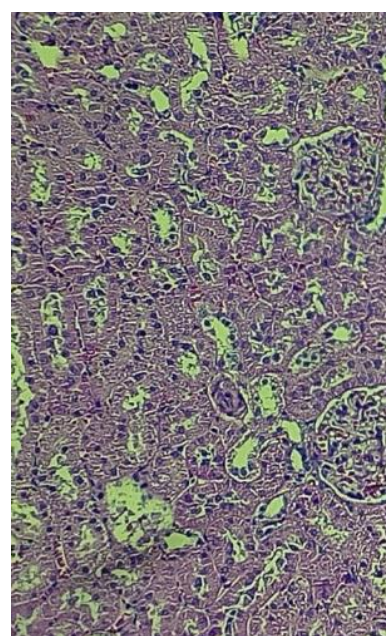

Perbesaran 100x
Gambar 16. Jaringan ginjal terdiri dari glumerulus dengan kapsula bowman terdiri dari sel dgn inti bulat, relatif uniform. Tampak tubulus 
tersusun rapat berstruktur tubulus dilapisi epitel kuboid selapis. Tak didapatkan nekrosis, tanda radang maupun keganasan.

\section{Kelompok (5)}

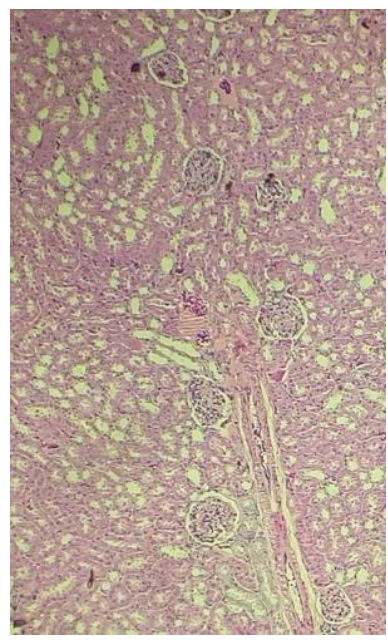

\section{Perbesaran 40x}

Perbesaran 100x

Gambar 17. Jaringan ginjal terdiri dari glumerulus dengan kapsula bowman terdiri dari sel dgn inti bulat, relatif uniform. Tampak tubulus tersusun rapat berstruktur tubulus dilapisi epitel kuboid selapis. Tak didapatkan nekrosis, tanda radang maupun keganasan.

\section{Kelompok (6)}
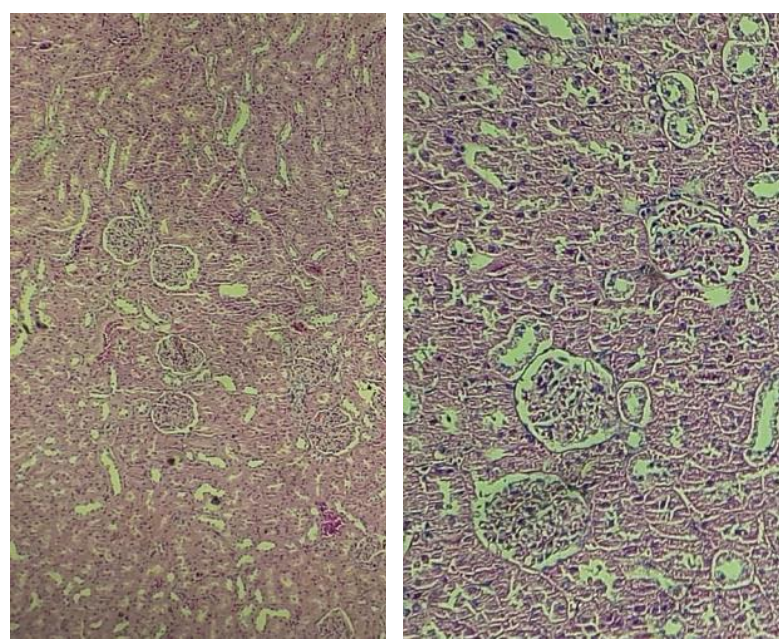

\section{Perbesaran 40x}

\section{Perbesaran 100x}

Gambar 18. Jaringan ginjal terdiri dari glumerulus dengan kapsula bowman terdiri dari sel dgn inti bulat, relatif uniform. Tampak tubulus tersusun rapat berstruktur tubulus dilapisi epitel kuboid selapis. Tak didapatkan nekrosis, tanda radang maupun keganasan.

\section{PEMBAHASAN}

Pada jaringan pankreas yang normal terlihat Jaringan pankreas terdiri dari kelenjar kecilkecil dilapisi epitel kuboid selapis dengan inti bulat, relatif uniform, tersusun mikrofolikuler. Diantaranya tampak pulau-pulau langerhans yg lebih pucat, dengan inti bulat relatif uniform. Pada kelompok 2 yang diberikan STZ terlihat sebagian sel tampak nekrosis, disertai sebukan sel radang kronik limfosit. Pada kelompok kontrol positif yang diberikan glibenklamid tidak didapatkan nekrosis dan sel radang minimal. Pada pemberian ekstrak dosis 250 $\mathrm{mg} / \mathrm{KgBB}$ jaringan pankreas mimiliki gambaran histoPA mirip dengan kontrol positif dimana tidak didapatkan sel nekrosis dan tampak sel radang minimal. Pada pemberian ekstrak dosis $500 \mathrm{mg} / \mathrm{KgBB}$ dan $1000 \mathrm{mg} / \mathrm{KgBB}$ memiliki hasil mendekati kontrol normal dimana jaringan pankreas terdiri dari kelenjar kecil-kecil dilapisi epitel kuboid selapis dengan inti bulat, relatif uniform, tersusun mikrofolikuler. Diantaranya tampak pulaupulau langerhans dgn sel lebih pucat, inti bulat, relatif uniform, tidak didapatkan sel nekrosis dan sel radang.

Jaringan hepar pada kelompok kontrol yang normal, kontrol negatif, kontrol positif dan kelompok perlakuan dengan pemberian ekstrak $250 \mathrm{mg} / \mathrm{KgBB}$ dan $500 \mathrm{mg} / \mathrm{KgBB}$ memiliki gambaran histoPA yang hamper sama dengan tidak ditemukannya nekrosis maupun sebukan sel radang pada sediaan ini. Pada kelompok perlakuan dengan dosis $1000 \mathrm{mg} / \mathrm{kgBB}$. Tampak pula sebukan moderat sel radang kronik limfosit setempat-setempat.

Jaringan ginjal pada kelompok kontrol terdiri dari glumerulus dengan kapsula bowman 
terdiri dari sel dgn inti bulat, relatif uniform. Tampak tubulus tersusun rapat berstruktur tubulus dilapisi epitel kuboid selapis. Tak didapatkan nekrosis, tanda radang maupun keganasan. Hal ini juga tampak pada kontrol negatif. Pada kontrol positif. Tampak pula tubulus yg tersusun rapat, berstruktur tubulus, dilapisi epitel kuboid selapis. Diantaranya tampak sebukan moderat sel radang kronik limfosit setempat-setempat disertai bagian perdarahan. Pada kelompok perlakuan dengan pemberian ekstrak dosis $250 \mathrm{mg} / \mathrm{KgBB}, 500$ $\mathrm{mg} / \mathrm{KgBB}$ dan $1000 \mathrm{mg} / \mathrm{KgBB}$ memiliki gambaran jaringan ginjal seperti kontrol normal yaitu tidak didapatkan nekrosis, tanda radang maupun keganasan.

zat diabetogenik aloksan dan streptozotocin bersifat toksik terhadap sel beta pankreas dan dapat menyebabkan insulitis pada hewan percobaan. Kerusakan sel beta pankreas menyebabkan tubuh tidak bisa menghasilkan insulin sehingga menyebabkan kadar glukosa darah meningkat (terjadi keadaan hiperglikemia). Kondisi hiperglikemia dapat menghasilkan pembentukan spesies oksigen reaktif (ROS=reactive oxygen species). ROS yang berlebihan dapat menyebabkan stres oksidatif dan dapat memperparah kerusakan sel beta pankreas. ROS yang berlebih ini meningkatkan kejadian stres oksidatif dan merusak sel beta pankreas. Pengamatan ultrastruktur pada kelompok tikus kontrol negatif terlihat jelas ditemukan sel alpha, sel beta, dan sel delta. Tampak jelas zimogen di bagian sel asinar, sekretori granula insulin, dan glukagon. Pada kelompok tikus kontrol positif diabetes (DM), terlihat pertautan sel asinar dengan pulau Langerhans lepas, sekretori granula insulin sangat berkurang, membran sel mitokondria rupture (bocor), serta beberapa mitokondria kehilangan kristae dan inti sel beta mengalami kariopiknotis
Antioksidan yang terkandung dalam tanaman digunakan untuk pencegahan dan perlindungan dari stress oksidatif kerusakan yang disebabkan oleh radikal bebas. Tanaman bungur memiliki kandungan kimia senyawa alkaloid, saponin, flavonoid dan tannin. Flavonoid merupakan senyawa polifenol yang ditemukan sebagai metabolit sekunder pada tanaman. Berbagai macam aktivitas farmakologi telah diuji terhadap golongan senyawa flavonoid seperti antioksidan, antiinflamasi, dan antikanker. Tanin berperan dalam memacu metabolisme glukosa dan lemak sehingga penimbunan zat tersebut di dalam darah dapat dihindari. Tanin memiliki aktivitas hipoglikemik selain itu juga dapat dikerutkan membran epitel pada usus halus sehingga sarisari makanan yang diserap serta asupan gula dapat dihambat. Hal ini membuat gula darah tidak meningkat terlalu tinggi. Polifenol berperan menurunkan kadar glukosa darah. Mekanisme kerja yang dilakukan yaitu pencegahan reaksi pengubahan superoksida menjadi hidrogen superoksida. Peran polifenol yaitu perlindungan sel $\beta$ pankreas dari efek toksik yang dihasilkan oleh radikal bebas dan diproduksi saat kondisi hiperglikemia kronis. Antioksidan berfungsi sebagai pencegah oksidasi yang berlebihan sehingga kerusakan pada sel $\beta$ pankreas dapat dikurangi dan dapat menyebabkan kadar glukosa darah turun. Selain itu dapat mempertahankan kandungan insulin..$^{38,39,40}$ 
Berdasarkan penelitian dosis ekstrak etanol batang Bungur (Lagerstroemia speciosa [L.] Pers) yang mendekati kontrol normal dengan dosis minimal adalah dosis 500 $\mathrm{mg} / \mathrm{KgBB}$ karena terlihat pada jaringan pankreas pemberian ekstrak dosis 250 $\mathrm{mg} / \mathrm{KgBB}$ jaringan pankreas memiliki gambaran sel radang minimal. Pada pemberian ekstrak dosis $500 \mathrm{mg} / \mathrm{KgBB}$ dan $1000 \mathrm{mg} / \mathrm{KgBB}$ memiliki hasil mendekati kontrol normal dimana jaringan pankreas terdiri dari kelenjar kecil-kecil dilapisi epitel kuboid selapis dengan inti bulat, relatif uniform, tersusun mikrofolikuler. Diantaranya tampak pulaupulau langerhans dgn sel lebih pucat, inti bulat, relatif uniform, tidak didapatkan sel nekrosis dan sel radang. Pada jaringan hepar pemberian ekstrak $250 \mathrm{mg} / \mathrm{KgBB}$ dan $500 \mathrm{mg} / \mathrm{KgBB}$ memiliki gambaran tidak ditemukannya nekrosis maupun sebukan sel radang pada sediaan ini sedangkan pada kelompok perlakuan dengan dosis $1000 \mathrm{mg} / \mathrm{kgBB}$ tampak sebukan moderat sel radang kronik limfosit setempat-setempat. Jaringan ginjal pemberian ekstrak dosis $250 \mathrm{mg} / \mathrm{KgBB}, 500 \mathrm{mg} / \mathrm{KgBB}$ dan $1000 \mathrm{mg} / \mathrm{KgBB}$ memiliki gambaran jaringan ginjal seperti kontrol normal yaitu tidak didapatkan nekrosis, tanda radang maupun keganasan.

Hasil penelitian yang dilakukan yang dilakukan oleh Fiizda Baqarizk tentang studi awal gambaran patologi pankreas, hati, dan ginjal pada tikus putih jantan (Rattus norvegicus) Model Diabetes Melitus Yang Diinduksi Streptozotocin (STZ) menunjukan bahwa tidak ada perbedaan bermakna antara kontrol positif dan kontrol negatif dari histoPA tikus yang diuji. Hasil penelitian ini sesuai dangan yang terjadi pada penelitian ini dimana tidak didapatkan perbedaan antara kelompok kontrol normal, kontrol negatif dan kontrol positif serta kelompok perlakuan P4,P5 dan P6. Hal ini disebabkan akibat dari jarak waktu antara pengambilan sampel organ dan induksi
STZ yang terlalu dekat, pada penelitian ini yaitu 28 hari, sehingga gambaran kelainan yang terjadi di organ ginjal tikus masih belum terlihat jelas secara HistoPA. Maka berdasarkan hal ini, penilaian terhadap seberapa besar pengaruh dari Ekstrak Batang Bungur (Lagerstroemia speciosa [L.] Pers) terhadap perbaikan dari organ ginjal tidak dapat dilakukan. Untuk itu, perlu dilakukan pengujian lain yang memberikan jarak antara pemnerian STZ dan pembedahan yang lebih lama untuk mendapatkan perbedaan struktur histoPA dan mendapatkan hasil efektif dari pengaruh Ekstrak Batang Bungur (Lagerstroemia speciosa [L.] Pers) di berbagai dosis pemberian yang berbeda.

\section{KESIMPULAN DAN SARAN}

\section{A. Kesimpulan}

1. Dosis efektif yang baik sebagai antidiabetes pada penelitian ini adalah ekstrak etanol batang Bungur (Lagerstroemia speciosa [L.] Pers) dosis $500 \mathrm{mg} / \mathrm{KgBB}$. Dosis ini mampu memberikan gambaran mendekati gambaran histo PA kelompok kontrol normal.

2. Hasil fitokimia membuktikan bahwa ekstrak etanol batang Bungur (Lagerstroemia speciosa [L.] Pers) mengandung kadar flavonoid yang tinggi dan berperan memperbaiki histologi jaringan dan status antioksidan pada tikus diabetes.

3. Tidak terdapat perubahan gambaran histoPA organ ginjal antara kelompok perlakuan Hal ini disebabkan oleh jarak waktu antara pengambilan sampel organ dan induksi STZ yang terlalu dekat, 
pada penelitian ini yaitu 28 hari, sehingga pengaruhnya terhadap organ ginjal masih belum terlihat jelas secara HistoPA.

\section{B. Saran}

1. Perlu dilakukan penelitian dengan jarak waktu antara pengambilan sampel organ dan induksi STZ yang lebilh lama untuk mendapatkan gambaran histoPA Hati dan ginjal tikus (Rattus Norvegicus) yang diinginkan

2. Perlu dilakukan penelitian lebih lanjut untuk mengetahui ekstrak batang bungur (Lagerstroemia speciosa [L.] Pers terhadap organ lain.

\section{DAFTAR PUSTAKA}

1. Chan, Margaret. Global Report On Diabetes. World Health Organization. 2014.

2. Soendoro, Triyono. Riset Kesehatan Dasar Tahun 2013. Badan Penelitian Dan Pengembangan Kesehatan Departemen Kesehatan Republik Indonesia.2013.

3. Sudoyo Aw, Setiyohadi B, Alwi I, Simadibrata M, Setiati S. Buku Ajar Ilmu Penyakit Dalam Jilid Ii Edisi Vi. Jakarta Pusat: Interna Publishing.

4. Soelistijo A S, Hermina N Dkk. Konsensus Pengelolaan Dan Pencegahan Diabetes Melitus Tipe 2 Di Indonesia 2015. Jakarta: Pengurus Besar Perkumpulan Endokrinologi Indonesia. 2015.

5. Annisa F, Viryawan C, Santoso F. Hipoksia Berpeluang Mencegah Kerusakan Sel B Pankreas Pada Pasien Diabetes Melitus Tipe 2: Tinjauan Biologi Molekular. Cdk-214.2014; 41 (3)

6. Akerele V, Heywood V, Synge H. The Conservation Of Medicinal Plants. Cambridge: Cambridge University Press. 1991.

7. Hernawan Ue, Sutarno, Setyawan Ad. Aktivfitas Hipoglikemik Dan Hipolipidemik Ekstrak Air Daun Bungur Terhadap Tikus Diabetik. Biofarmasi
Journal Of Pharmacological And Biological Science. 2004:15-23.

8. Rochman J. Studi Aktivitas Ekstrak Daun Bungur Dan Maitan (Lunasia Amara Blanco) Sebagai Antioksidan Serta Inhibitor -Amilase Dan -Glukosidase. [Skripsi]. Jember : Jurusan Kimia Fakultas Matematika Dan Ilmu Pengetahuan Alam Unversitas Jember. 2012 ; 6-7

9. Asih, Astiti I. Setiawan Ma. Senyawa Golongan Flavonoid Pada Ekstrak NButanol Kulit Batang Bungur (Lagerstroemia Speciosa Pers.). Fmipa. Universitas Udayana. 2008:115.

10. Cuvelier M E, Richards H, And Besset C. 1994. Comparison Of The Antioxidative Activity Of Some Acid Phenols: StructureActivity Relationship, Biosci. Biothech. Biochem. 56(2), 324 - 325.

11. Baqarizky, Fiizhda. Studi Awal: Gambaran Histopatologik Pankreas, Hati Dan Ginjal Tikus Diabetes Mellitus Yang Diinduksi Streptozotocin Dengan Pewarnaan Hematoksilin Eosin. [Skripsi]. Jakarta. Fakultas Kedokteran Dan Ilmu Kesehatan Uin Syarif Hidayatullah Jakarta. 2015.

12. Szkudelski T. The Mechanism Of Alloxsan And Streptozotocin In B Cells Of The Rat Pancreas. Physiol Res. 2001. 50: 536-546.

13. Gilman Ga, Hardman $\mathrm{Gj}$, Limbird Le. Goodman \& Gilman Dasar Farmakologi Terapi Edisi 10. Volume 4. Jakarta: Penerbit Buku Kedokteran Egc, 2012.

14. Price Sa, Wilson Lm. Patofisiologi Konsep Klinis Proses-Proses Penyakit Edisi 6 Volume 2. Jakarta: Penerbit Buku Kedokteran Egc: 2006.

15. Wahyuni E. Pengaruh Pemberian Folat Terhadap Kadar Homosistein Serum Dan Malodialdehid Plasma Studi Eksperimental Pada Tikus Sprague Dawley Yang Diinduksi Streptozotocinm [Tesis]. Semarang: Universitas Diponegoro.2011.

16. Athiyah U, Riskayanti E. Profil Informasi Obat Pada Pelayana Resep Metformin Dan Glibenklamid Di Apotek Di Wilayah 
Surabaya. Jurnal. Departemen Farmasi Komunitas

17. Orwa C, Mutua A, Kindt R, Jamnadass R, Simons A. Agroforestree Database: A Tree Reference And Selection Guide Version 4.0. Kenya : World Agroforestry Centre. 2009.

18. Bramasto Y. Nurhasybi. Danu. Syamuida D. Zanzibar M. Pujiastuti E. Mokodompit S. Trees Of The City Profil Tanaman Hutan Untuk Perkotaan Wilayah Jawa Barat, Banten Dan Dki Jakarta.

19. Wahyuni N. Efek Jamur Tiram Putih (Pleurotus Ostreatus) Terhadap Sel Beta Pankreas Tikus Wistar Jantan Model Diabetes Mellitus Tipe 2 Yang Diberi Pakan Tinggi Lemak Dan Streptozotocin Dosis Rendah. [Tesis]. Universitas Sumatera Utara. Medan. 2014

20. Irwan F. Aktivitas Antidiabetes Dan Analisis Fitokimia Ekstrak Air Dan Etanol Daun Wungu (Graptophyllum Pictum (L.) Griff). Institut Pertanian Bogor. 2011. Diunduh Dari

Http://Repository.Ipb.Ac.Id/Jspui/Bitstrea m/123456789/52533/11/G11fir1.Pdf

21. Syaputri Rr. Uji Efek Ekstrak Etanol $70 \%$ Kulit Buah Asam Jawa (Tamarindus Indica L) Terhadap Penurunan Kadar Glukosa Darah Tikus Jantan Galur Wistar (Rattus Norvegicus) Yang Diinduksi Aloksan. Universitas Muhammadyah Surakarta. 2013

22. Fiizhda Baqarizky. Study awal : Gambaran Histopatologik pankreas, hati dan ginjal tikus diabetes melitus yang diinduksi Streptozotocin dengan pewarnaan hematoksilin eosin. Jakarta : Program studi pendidikan dokter UIN Syarif Hidayatullah, 2015

23. Rarangsari, Novi Endah. Pengaruh ekstrak daun Sirsak (Annona Muricata L) Terhadap SOD dan Histologi Hati Tikus (Rattus norvegicus) yang diinduksi aloksan. Malang : Fakultas sains dan teknologi, Universitas Islam Negeri Maulana Malik Ibrahim, 2015.

24. Ardiani, F., Wiryatun L., dan Emy H.2011. Ekstrak Air daun Ceplikan (Ruellia tuberose L.) Berpengaruh terhadap kadar SGOT,SGPT dan gambaran Histologi Hati
Tikus DM. Jurnal Gizi Klinik Indonesia. Vol.8, No.2

25. Herlina pratiwi, djoko winarso, nunung handoyo. Kadar low density lipoprotein dan gambaran histopatologi hati pada tikus model diabetes mellitus tipe 1 dengan pemberian Ekstrak etanol curcuma longa l. Malang : Program Studi Pendidikan Dokter Hewan, Fakultas Kedokteran Hewan, Universitas Brawijaya,2015. 